\title{
Diethylphthalate, Possible Interactions in Fetal Brain Development
}

\author{
R. Hokanson ${ }^{1}$, R. Chowdhary ${ }^{1}$ and D. Busbee ${ }^{1,2, *}$
}

\author{
${ }^{I}$ Department of Integrative Biosciences, College of Veterinary Medicine and Biomedical Sciences, Texas A\&M Univer- \\ sity and ${ }^{2}$ Department of Environmental and Industrial Health, School of Rural Public Health, TAMU Health Science \\ Center, Texas A\&M University, College Station, TX 77843, USA
}

\begin{abstract}
Many natural and synthetic compounds, including a variety of the chemicals used as plasticizers or in the production of cosmetics and therapeutics, have steroid agonist or antagonist activities, altering hormone-regulated gene expression. The phthalate (diethylphthalate, extensively used as a plasticizer and in consumer products, are evaluated using the human renal epithelial cell line 293T/17. Emphasis of the study was on genes essential for central nervous system development or function. Cells were treated with 1,10 or $100 \mu \mathrm{M}$ phthalate and gene expression was measured in treated cells, showing significant up- or down-regulation of a large number of genes in treated compared to untreated cells. Of the 19,000 human genes on the DNA array chip utilized, two specific genes, FGD1 and NGPF2, were selected to corroborate mRNA levels using quantitative real time PCR (qrtPCR) data to confirm results obtained from the microarray determinations. FGD1 (faciogenital dysplasia) and NGPF2 (neurite growth-promoting factor 2, also called Midkine, MDK), showed a significant, possibly estrogen-synergistic, down-regulation of genes essential for fetal brain development. These studies were designed to provide data on the gene expression-altering capacity of a widely distributed chemical, diethylphthalate (DEP), and to show possible associations between the previously reported widespread presence of DEP and the DEP metabolite, MEP, in urine samples from a reference population, the potential for altered gene expression in human cells in vitro, and possible neurodevelopmental effects that could be correlated with in utero exposure to DEP.
\end{abstract}

Key Words: Gene expression, DNA microarray analysis, plasticizers, phthalates, qrtPCR.

\section{INTRODUCTION}

The phthalates, diesters of phthalic acid, are a group of organic chemicals used in the production of a variety of personal, consumer, and medical products [1]. They are widely used in the manufacture of a number of products made from polyvinylchlorides (plastics) which have been softened for injection or extrusion molding by the inclusion of one or more of a variety of plasticizers, including one of the variety of phthalates. Plastic containers for milk, fruit juice, water, and food packaging materials may leach phthalates, some of which are reported to be reproductive and developmental toxicants [2]. In addition, many cosmetics contain phthalates as stabilizers of scents and color, and a number of medications may contain phthalates as formulants of enteric coatings [3]. Phthalates may leach from solution storage bags and tubing used in blood transfusions, enteral and parenteral nutritional support, and kidney dialysis [4-6]. Phthalates and their metabolites have been found in urine samples from a reference population [4-6], and diethylphthalate has been been reported to be present at variable levels in urine samples from $100 \%$ of males evaluated [7]. Phthalates and their monoester metabolites have been reported to be androgen antagonists [8], initiators of tumors in rats [9], to alter the expression of a large number of genes with known estrogenic regulation [10], and to interfere, as a function of phtha-

*Address correspondence to this author at the Department of Integrative Biosciences, College of Veterinary Medicine and Biomedical Sciences, Texas A\&M University, College Station, TX 77843, USA; Tel: 979-8452828; Fax: 979-847-8981; E-mail: dbusbee@cvm.tamu.edu late estrogenicity, with chemotherapy-induced apoptosis in human breast cancer cells [11]. While a number of phthalates, including diethylphthalate, are considered to be endocrine interactive, their mechanisms of toxicity are not well understood, but are thought to be functions of the disruption of gene expression by interaction with one or more of the nuclear steroid receptors.

Steroid receptors are a structurally related group of cellular proteins which bind with reasonably high specificity to both the steroid hormones and to specific upstream genetic regulatory elements. Receptor binding of steroid hormones and interaction of homo-or heterodimeric receptor-ligands with specific regulatory elements are essential events for hormone-regulated gene expression necessary for maintaining endocrine-interactive physiological functions in eukaryotic organisms [12]. Humans are chronically exposed to low levels of a variety of plasticizers as formulants of enteric coatings on drugs, cosmetic components, as compounds leeching into food or water, and as environmental contaminants, many of which may disrupt steroid hormone-regulated physiological activities. A number of these chemicals are endocrine-interactive because they bind steroid hormone receptors or in some way interact within the cell to up- or down-regulate expression of endocrine-regulated genes.

Extensive recent research has lead to an understanding of the cause and effect relationship between exposure to chemicals that have endocrine disruptive activities (endocrine disruptive chemicals; EDC) and the initiation of altered endocrine-regulated physiological functions in animals. Chemi- 
cally-initiated changes in gene expression may lead to changes in synthesis of essential enzymes, structural, or regulatory proteins resulting in altered gender determination, neurodevelopmental and/or morphological alterations, and decreased normal immune system responses to infectious agents [13-22]. Morphological and neurodevelopmental changes in utero after exposure of pregnant animals to EDC may result in a variety of birth defects related to gene dysfunction which may occur even though concentrations of the offending chemicals may be quite low in the environment [16, 23-32].

In this paper the authors present data from an investigation of DEP (Fig. 1) alteration of gene expression in the human cell line 293T/17. A large number of the 19,000 genes on the chip used for these studies showed statistically valid dysregulation, that is up-regulation by $100 \%$ (to a tetraploid level), or down-regulation by at least $50 \%$ (to a haploid level). Two of these genes, FGD1 (faciogenital dysplasia) and NGPF2 (neurite growth-promoting factor 2, also called Midkine, $M D K$ ) were selected for further corroboration from a list of neurodevelopmentally associated genes that were dysregulated (Table 1). Both of these genes have been classified as being in the group known, in mutant form, to be associated with fetal brain developmental abnormalities.

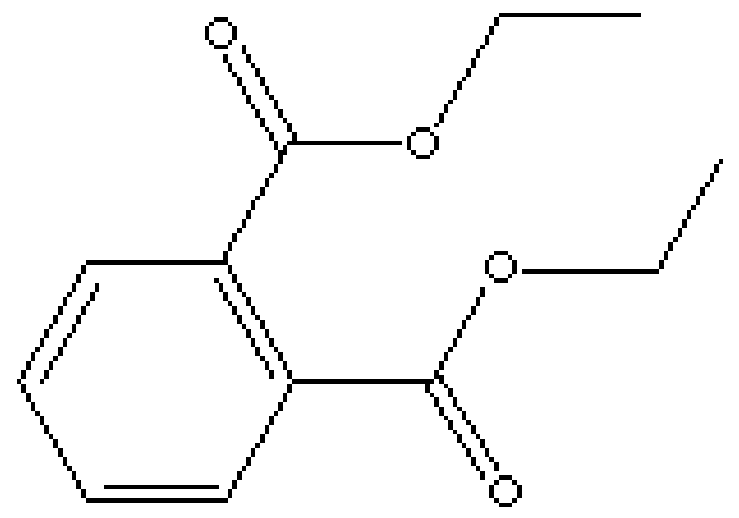

Fig. (1). Structure of diethylphthalate, DEP.

\section{MATERIALS AND METHODS}

\section{Tissue Culture}

The human renal epithelial cell line, 293T/17, obtained from ATCC (Manassas, VA), was grown in Dulbecco's modified Eagle's medium (DMEM, Sigma, St. Louis, MO) supplemented with $10 \%$ fetal bovine serum (FBS, Atlanta Biologicals, Laurenceville, GA), 4mM L-glutamine, and $1.5 \mathrm{~g}$ sodium bicarbonate/liter (both from Sigma, St. Louis, MO). Cells were then switched to DMEM with steroidstripped FBS for $18 \mathrm{hr}$ to reduce exposure to estrogens. This was followed by treatment for another $18 \mathrm{hr}$ with or without diethylphthalate (DEP) at 1,10 , or $100 \mu \mathrm{M}$ concentrations in the presence or absence of $3 \times 10^{-10} \mathrm{M} 17 \beta$-estradiol (E2). This is very close to the growth and development optimum of $17 \beta$-estradiol determined for another human cell line, MCF-7, by Miller et al., [33].

\section{Total RNA Extraction and Quantification}

Cells were harvested at the end of $36 \mathrm{hr}$ of treatment using a lysis solution from Ambion (Austin, TX) and stored at $-80^{\circ} \mathrm{C}$ until RNA was purified. RNA was extracted from the lysate using Ambion's Totally RNA kit, spectrophotometrically quantified, and evaluated on a $1 \%$ agarose denaturing gel to check for quality.

\section{cDNA Microarray}

Fluorescently labeled cDNA was prepared from total RNA using a SuperScript III kit from Invitrogen (Carlsbad, CA). Control cDNA (SFBS cultured cells) were labeled with cyanine 5 and test cDNA (DEP+E2 treated cells) was labeled with cyanine 3 (both dyes from Amersham, Piscataway, NJ) before combining them in a 1:1 ratio and allowing cDNAs to hybridize to the 19,000 single human gene arrays from the University Health Network Microarray Center (University of Toronto, Toronto, Canada). All arrays were done in quadruplicate. The hybridization reaction was completed at $37^{\circ} \mathrm{C}$ for $16 \mathrm{hr}$ in a humidified environment. Slides were washed in sodium dodecyl sulfate-saline sodium citrate buffers of increasing stringency to remove unbound labeled cDNA. Slides were then centrifuged in a 50cc conical tube to remove residual buffer.

\section{Array Scanning and Data Analysis}

Total RNA recovered after TRIzol isolation was less than $75 \mu \mathrm{g} / \mathrm{sample}$. Microarray reactions were completed according to the protocol for the MICROMAX ${ }^{\mathrm{TM}}$ TSA (Tyramide Signal Amplification) Labeling and Detection Kit (Perkin Elmer Life Sciences, Boston, MA). This kit is specifically designed for amplification and detection of small amounts of RNA. Details of this protocol may be obtained from the Perkin Elmer web site (Ref: MICROMAX TSA Labeling and Detection Kit). Slides were stringently washed $\mathrm{x} 3$ at room temperature in $0.5 \mathrm{X}$ SDS, $0.06 \mathrm{X}$ SSC/0.01\% SDS, placed into a $50 \mathrm{~mL}$ polypropylene tube, and centrifuged at $500 \mathrm{xg}$ for $5 \mathrm{~min}$ to remove excess liquid prior to scanning. Microarray slides were scanned in a BioChip Imager (Packard, Meridien, CT). Laser and photomultiplyer tube voltages (PMT) were manually adjusted to maximize signal to noise ratio. Signal intensities were standardized relative to one another by comparing the total signal intensities of all spots in each channel. The scanner output images were quantified using ScanAlyze software (developed by Michael Eisen, University of California, Berkeley, CA). Statistical analysis utilized one-way ANOVA followed by Dunnett's test to analyze differences between control and chemically-treated samples, with $\mathrm{P}<0.05$ considered to be statistically significant.

\section{Reverse Transcription}

$1 \mu \mathrm{g}$ of high quality total RNA was used for reverse transcription. Briefly, for a $25 \mu$ RT reaction, random hexamers $(16 \mu \mathrm{M}$ final concentration, Roche, Indianapolis, IN), Oligo dT (500ng/ $\mu$ l, Promega, Madison, WI), RNA $1.0 \mu \mathrm{g}$, and RNAse-free water were combined, heated at $65^{\circ} \mathrm{C}$ for $5 \mathrm{~min}$, and allowed to cool to room temperature. A cocktail of the following components was added to each sample: $5 \mathrm{X} 1^{\text {st }}$ strand buffer, 0.1M DTT (both included with SuperScript II), RNase block (Brinkman, Westbury, NY), 10mM dNTPs (Promega, Madison, WI) and SuperScript II RT (Invitrogen, Carlsbad, CA). Cocktail was also made without RT as a control. Each tube was mixed and centrifuged briefly. The RT 
Table 1. A Partial List of CNS-Specific Genes Dysregulated by DEP

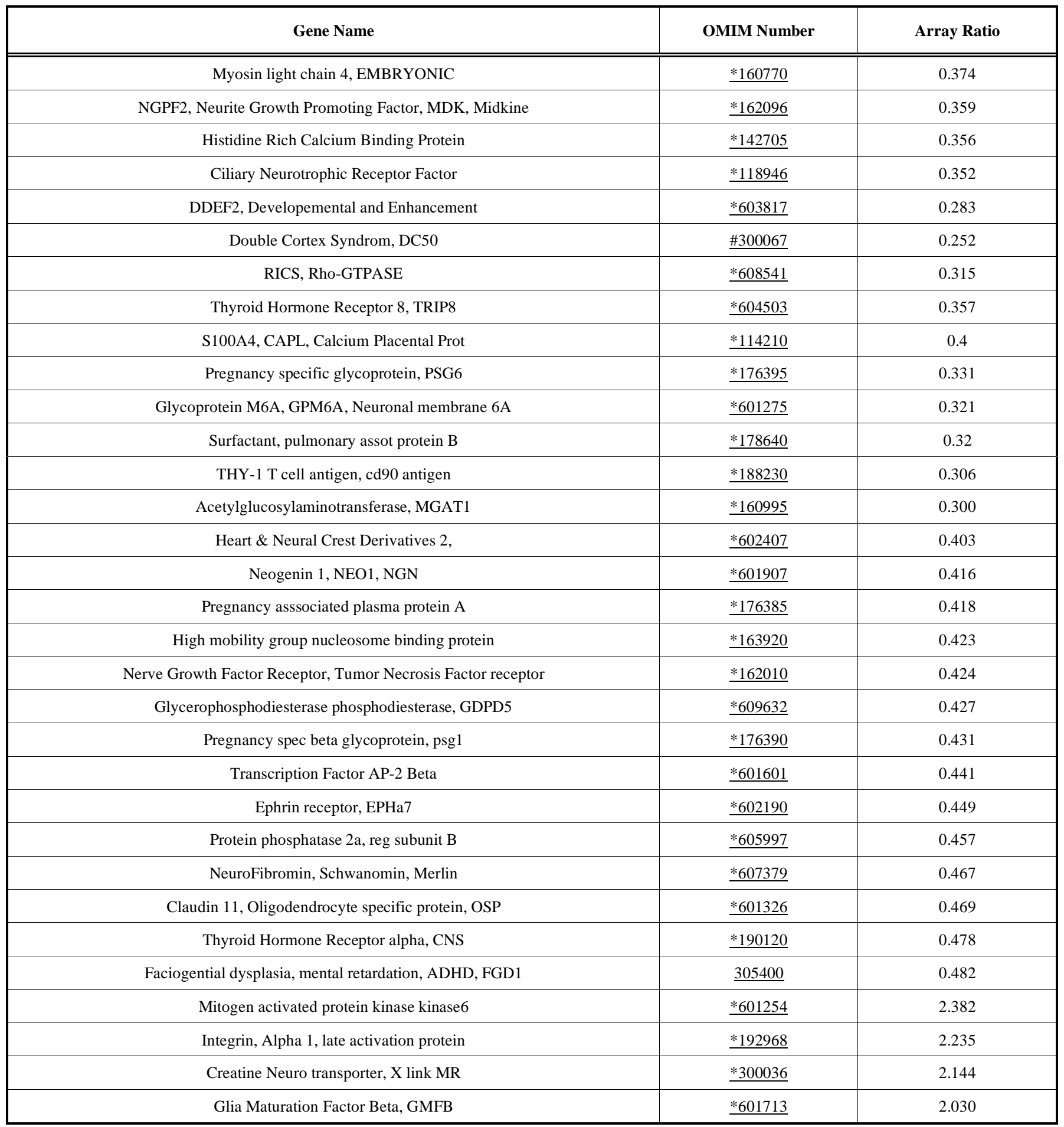

Table 1 was constructed to provide the reader with OMIM numbers to retrieve data on function of the specific gene.

reaction was continued at $37^{\circ} \mathrm{C}$ for $1 \mathrm{hr}$. Reverse transcriptase was inactivated by heating at $90^{\circ} \mathrm{C}$ for 5 minutes and samples were cooled on ice or stored at $-80^{\circ} \mathrm{C}$.

\section{Quantitative Real Time PCR (qrtPCR)}

Twenty-three $\mu \mathrm{L}$ of a cocktail containing Universal PCR master mix, no-UNG, from ABI (Branchburg, New Jersey), pre-made ABI expression assays (primers) specific for the genes of interest, FGD1 (Hs00171676_m1) or NGPF2 (Hs00171064_m1), and RNAse/DNAse-free water were combined with $2 \mu \mathrm{L}$ of each reverse transcription reaction in triplicate, plated into a semi-skirted 96-well PCR plate, and sealed with optically clear mylar film. qrtPCR Employed an Applied Biosystems 7500 Real Time PCR System thermocycler (Foster City, CA) using a 3 step cycling program rec- 
ommended by ABI: One cycle at $95^{\circ} \mathrm{C}$ for 10 min and forty cycles of $\left(95^{\circ} \mathrm{C}\right.$ for $15 \mathrm{sec}$ followed by $60^{\circ} \mathrm{C}$ for $\left.1 \mathrm{~min}\right)$.

\section{RESULTS}

Human renal epithelial cells were grown in medium containing 10\% normal FBS (NFBS), and changed to medium with steroid stripped FBS (SFBS) for $18 \mathrm{hr}$ before treatment with DEP $(1,10$, or $100 \mu \mathrm{M})$, with or without $17 \beta$-estradiol (E2). Cells were harvested after $36 \mathrm{hr}$, RNA was isolated and microarray slides were labeled to examine the effects of DEP on gene expression. A partial list of genes on the Toronto chip that were dysregulated by DEP, are endocrine interactive, and known to be important in fetal CNS development is given in Table 1. For verification of microarray data, expression dysregulation, the genes $F G D 1$ and $N G P F / M D K$, which showed significant down-regulation on the DNA array, with ratios of 0.482 and 0.359 respectively, were chosen for qrtPCR evaluation.

Both FGD1 and NGPF2/MDK showed significant downregulation by $10 \mu \mathrm{M}$ DEP as determined by qrtPCR analysis. These data from DEP-treated cells confirmed results of the DNA microarray analysis, with normalized expression levels for $F G D 1$ computed to cross the threshold line at least 1 complete cycle later than the untreated sample for $F G D 1$ and 1.5 cycles later for $N G P F 2$ at $10 \mu \mathrm{M}$ DEP (Fig. 2A, 2B). At $100 \mu \mathrm{M}$ DEP the data indicated at least a 5 cycle down-

A

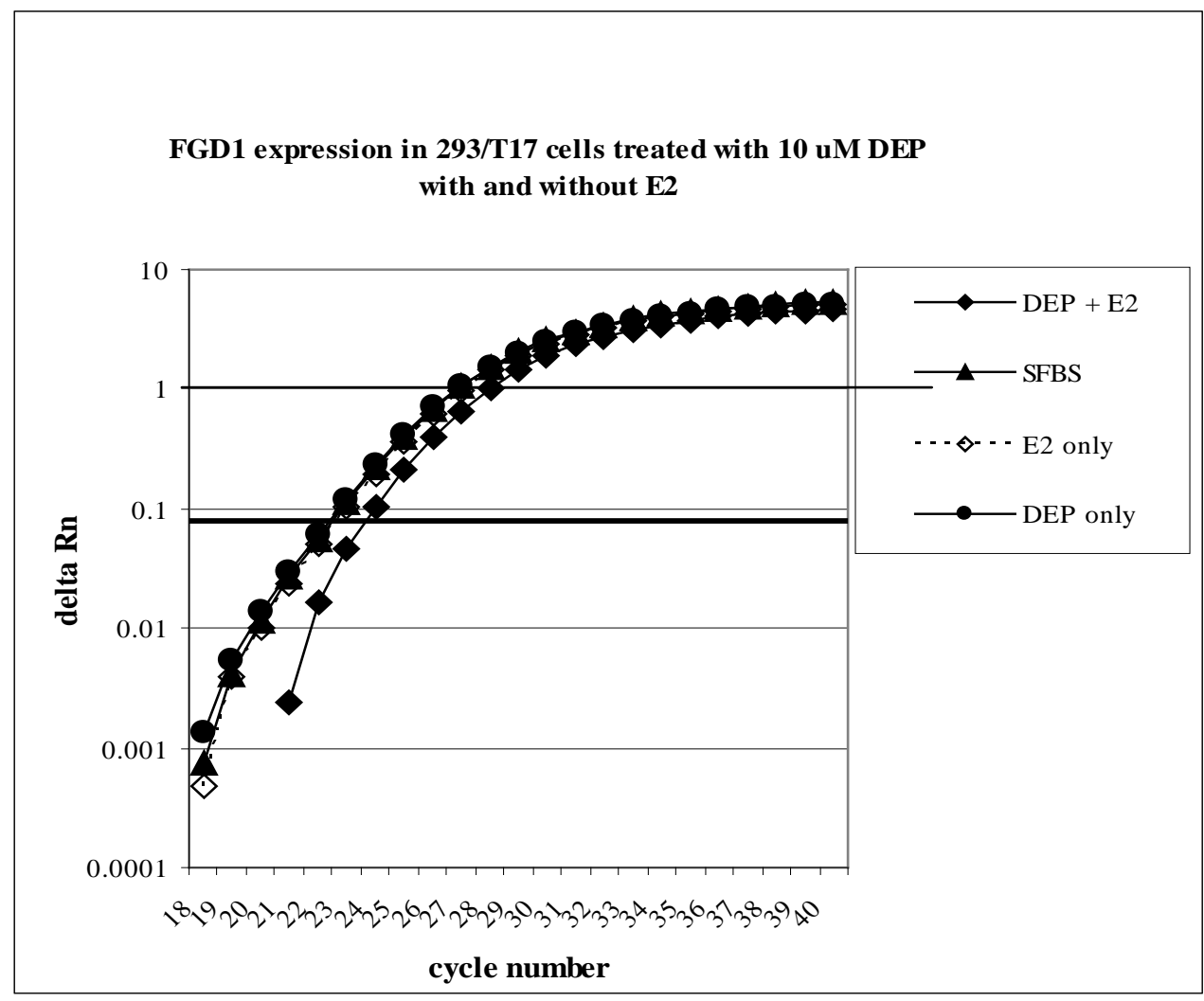

B

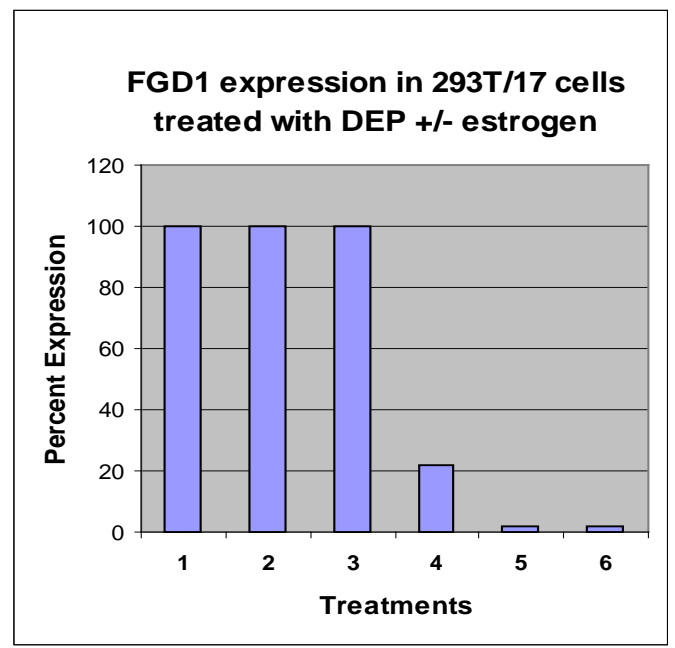

1. estrogen, 2. SFBS, 3. 10 uM DEP, 4. 10 uM DEP + estrogen, 5. 100 uM DEP, 6. 100 uM DEP + estrogen

Fig. (2). qrtPCR Plots provided using specific FGD1 Primers in human cell extracts after varying treatments. 
regulation of FGD1 expression. These data suggest a reduction in expression to a point greater than $25 \%$ but less than $50 \%$ of expression seen for control cells for both genes at $10 \mu \mathrm{M}$ DEP, and down-regulation of FGD1 to less than $10 \%$ of the control by $100 \mu \mathrm{M}$ DEP. qrtPCR Values for $N G P F 2$ were below consistently detectable levels in cells treated with $100 \mu \mathrm{M}$ DEP, a functional level just above 0.00 . A comparison of DEP with phthalic acid, rather one of the phthalate esters, indicated that phthalic acid itself was not gene expression inhibitory (data not shown).

\section{DISCUSSION}

The phthalates are a family of organic chemicals used to stabilize colors and scents in a variety of shampoos and cosmetics [9], as solvents in insect repellant sprays, paint, and glue [34], as components of some drug coatings, and as solubilizers in a wide variety of plastics, including food wraps, water bottles, milk containers, and medical products $[35,36]$. The widespread use of phthalates results in exposure of humans through a number of routes, including ingestion, dermal absorption, exposure from medical tubing and infusion sets, and from inhalation [3, 37-41].

With the development of analytical methods to detect and quantify esters of phthalates in urine, phthalate levels have been determined in large numbers of urine samples [3, 5, 6, 38,39 ] from both reference and random populations. These studies have lead to the disturbing conclusion that the vast majority of humans have detectable levels of phthalate metabolites in their urine, and that all males in a specific reference population have the primary urinary metabolite of diethylphthalate, MEP, in their urine samples. Very little is known about the mechanisms of DEP, and/or its metabolite MEP, toxicity, but they are generally considered to be estrogen agonists and androgen antagonists [39-44].

Data presented here suggest strongly that cellular exposure to DEP is correlated with dysregulation of a number of genes identified as having an association with development and/or function of the fetal brain. Of the genes shown in Table 1 that are dysregulated by DEP, FGD1 and NGPF2 were selected for qrtPCR corroboration. FGD1 was downregulated to slightly less than $50 \%$ of control and NGPF2 to between $25 \%$ and $50 \%$ of control levels by $10 \mu \mathrm{M}$ DEP. At $100 \mu \mathrm{M}$ DEP, FGD1 was down-regulated almost two full cycles, equivalent to expression at $25 \%$ of the control value, and $N G P F 2$ was downregulated to a level barely detected by qrtPCR.

Faciodigitogenital syndrome, the human disorder associated with FGD1, (also called Aarskog-Scott syndrome, AAS, and FGDY), is group of closely related disorders initially described by Aarskog over thirty years ago [45]. Children with this highly variable disorder may have ocular hypertelorism, anteverted nostrils, a broad filtrim, an altered anal-togenital distance, and a deformed penal and scrotal area that has been called shawl scrotum. AAS children show a frequent occurrence of connective tissue abnormality displayed as hyperextensibility of the fingers, genu recurvatum, and flat feet. Excessive variable laxity in the cervical spine is common, with anomalies of the odontoid region often seen associated with neurologic deficit. A recent paper reported attention deficit hyperactivity disorder, ADHD (44), in Aarskog-Scott syndrome children. Significant mental retardation is not always present in AAS children, and is not necessarily the same even in two families with the same mutation (Orrico et al., 2004). However, Fryns [48] estimated that cognitive impairment at some level may be as high as $30 \%$ in all persons presenting with Aarskog-Scott syndrome.

AAS mimicry of several other syndromes has confounded the diagnosis and reporting of this disorder, and even within a family group physical and mental differences may be quite variable. Although there is some disagreement on the mode of inheritance, most data support the finding that AAS is X-linked recessive [49] with a map locus of Xq11-12. Males with AAS are reported to be reproductively competent [50, 51], while females can display a variable form of the syndrome and are reproductively unimpaired, but are reported to show a mild form of the disorder [52]. The majority of variant types of AAS appear to be associated with mutation of the FGDl gene, and suggest an association between $F G D 1$ and $F G D 2$ expression essential for normal fetal morphological and neurological development. When one considers the data correlating FGD1 mutations and decreased anogenital distance in neonatal males, along with recent reports of decreased anogenital distance in neonatal males exposed to DEP, and recent reports that neonates in intensive care facilities are routinely exposed to DEP [3], there appears to be the possibility of a strong correlation between diminished FGD1 expression, DEP exposure, and the physical characteristics associated with AAS.

$N G P F 2$ is one of a group of highly conserved human genes that are apparently regulated by steroid hormones during development. The gene product has neurite outgrowth promoting activities, and as such, is likely a factor in promoting CNS development in utero. NGPF2 is expressed over a short span during the late second and early third trimesters, when major neural development occurs. The protein encoded by $N G P F 2$ is a 143 amino acid precursor for a functional protein with 121 amino acids which is partially homologous to a different heparin-binding neuronal outgrowth promoting factor, NGPF1. Both NGPF1 and 2 have neurotrophic activities, but map to different loci [32, 53-55]. A variety of studies have reported that $N G P F 2$ expression is essential for normal fetal brain development, but its precise mode of action remains unclear.

DNA microarray analysis, followed by qrtPCR corroboration of the microarray data, demonstrated here that exposure of human cells to DEP in vitro is consistent with initiation of decreased expression of a large number of genes that have been identified as essential for fetal brain development The analyses indicate that two genes, FGD1 and NGPF2, exhibit decreased expression in human cells exposed to DEP at concentrations as low as $10 \mu \mathrm{M}$, and suggest the possibility that decreased in utero expression of these genes would be likely to occur if the developing fetus was exposed to DEP at pharmacologically relevant concentrations. The degree to which developing embryos or neonatal infants show neurodevelopmental changes associated with decreased expression of NGPF2 is not clear at this time. In summary, these studies suggest that failure to develop of a normal brain/central nervous system may occur due to in utero, and perhaps to early post-natal, exposure to DEP or its metabolite MEP. Existing clinical studies have linked these two genes with a curious variety of morphological anomalies and an equally 
$\mathbf{A}$

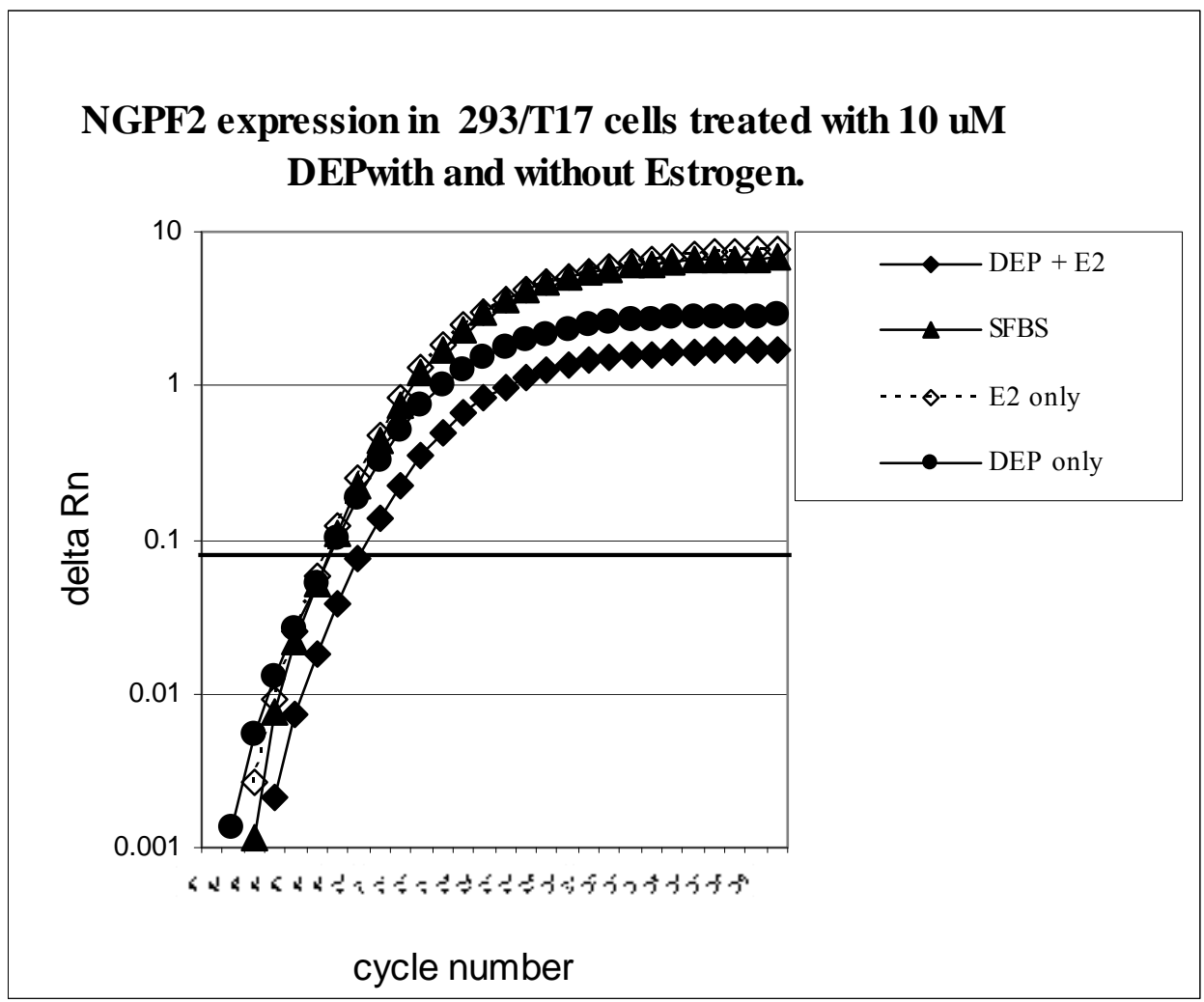

B

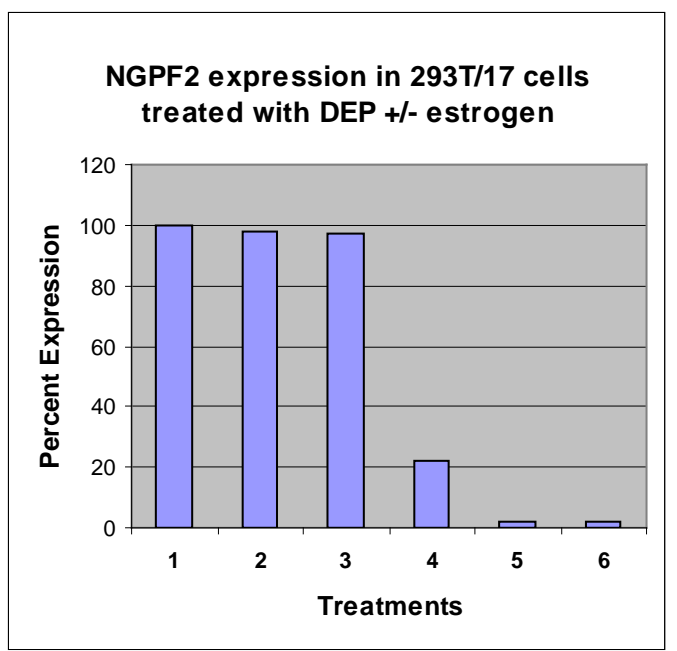

1. estrogen, 2. SFBS, 3. $10 \mathrm{uM}$ DEP, 4. $10 \mathrm{uM}$ DEP + estrogen, 5. $100 \mathrm{uM} \mathrm{DEP,} \mathrm{6.} 100 \mathrm{uM} \mathrm{DEP} \mathrm{+} \mathrm{estrogen}$

Fig. (3). qrtPCR Plots provided using specific MDK/NGPF2 Primers in human cell extracts after varying treatments.

curious variety of neurodevelopmental and functional disorders, notably, mental retardation and attention deficit hyperexcitability disorder, ADHD. Considering that essentially all males tested have been shown to have detectable DEP metabolites in their urine, and that $9.3 \%$ of children in the United States have been diagnosed as having ADHD, this could be a significant finding. However, at this time it is not known if the endocrine dysfunction and phthalate-altered gene expression presented here in an in vitro investigation can be correlated with any instance of in vivo phthalate exposure or human disease.

\section{ACKNOWLEDGEMENTS}

Supported in part by USEPA STAR award 430891, the TAMU Center for Environmental \& Rural Health award, P30 ESO9106, and an award from CDC/NIOSH 1 U50 $\mathrm{OH} 07541$ to the Southwest Center for Agricultural Safety and Health, University of Texas Health Center at Tyler.

\section{REFERENCES}

[1] Swan SH, Main KM, Liu F, et al. Decreased anogenital distance among male infants with prenatal phthalate exposure. Environ Health Perspect 2005; 13(8): 1056-61. 
[2] McKee RH, Butala JH, David RM, Gans G. NTP center for the evaluation of risks to human reproduction reports on phthalates: addressing the data gaps. Reprod Toxicol 2004; 18(1): 1-22. Review.

[3] Hauser R, Duty S, Godfrey-Bailey L, Green AM. Medications as a source of human Exposure to phthalates. Envrion Health Perspect 2004; 112(6): 751-3.

[4] Blount BC, Silva MJ, Caudill SP, et al. Levels of seven urinary phthalate metabolites in a human reference population. Environ Health Perspect 2000; 108(10): 972-82.

[5] Becker K, Seiwert M, Angerer J, et al. DEHP metabolites in urine of children and DEHP in house dust. Int $\mathrm{J}$ Hyg Environ Health 2004; 207(5): 409-17.

[6] Kato K, Silva MJ, Reidy JA, et al. Mono(2-ethyl-5-hydroxyhexyl) phthalate and mono-(2-ethyl-5-oxohexyl) phthalate as biomarkers for human exposure assessment to di-(2-ethylhexyl) phthalate. Environ Health Perspect 2004; 112(3): 327-30.

[7] Green R, Hauser R, Green AM, et al. Use of di(2-ethylhexyl) phthalate-containing medical products and urinary levels of mono(2-ethylhexyl) phthalate in neonatal intensive care unit infants. Environ Health Perspect 2005; 113(9): 1222-5.

[8] Stroheker T, Cabaton N, Nourdin G, Regnier JF, Lhuguenot JC, Chagnon MC. Evaluation of anti-androgenic activity of di-(2ethylhexyl)phthalate. Toxicology 2005; 208(1): 115-21.

[9] Voss C, Zerban H, Bannasch P, Berger MR. Lifelong exposure to di-(2-ethylyhexly) phthalate induces tumors in liver and testes of Sprague Dawley rats. Toxicology 2005; 206(3): 359-67.

[10] Hokanson R, Hanneman W, Hennessey M, Donnelly KC, McDonald T, Busbee D. DEHP, Bis(2)-ethylhexyl phthalate, alters gene expression in human cells: possible correlation with initiation of fetal developmental abnormalities. Hum Exp Toxicol 2006; 12: 68795.

[11] Kim IY, Han SY, Moon A. Phthalates inhibit tamoxifen-induced apoptosis in MCF-7 human breast cancer cells. J Toxicol Environ Health Part A 2004; 67: 2025-35.

[12] Fuller P. The steroid receptor superfamily: mechanisms of diversity. FASEB J 1991; 5: 3092-9.

[13] Jackson TF, Halbert FL. A toxic syndrome associated with the feeding of polybrominated biphenyl-contaminated protein concentrate to dairy cattle. J Am Vet Med Assn 1974; 165: 437-9.

[14] Constable JD, Hatch MC. Reproductive effects of herbicide exposure in Vietnam: recent studies by the Vietnamese and others. Terat Carcinog Mutagen 1985; 5: 231-50.

[15] Kashimoto T, Miyata H. Differences between Yusho and other kinds of poisoning involving only $\mathrm{PCBs}$, in "PCBs and the Environment", In: Waid JS, Ed. CRC Press, Boca Raton FL 1987.

[16] Lawrence C, Reilly A, Quyickenton P, Greenwald P, Page W, Kuntz A. Mortality patterns of New York State Vietnam veterans. Am J Public Health 1985; 75: 277-84.

[17] Colborn T, Vom Saal FS, Soto AM. Developmental effects of endocrine-disruptive chemicals in wildlife and humans. Environ Health Perspect 1993; 101(5): 378-83.

[18] Abbott BD, Perdew GH, Buckalew AR, Birnbaum LS. Interactive regulation of $\mathrm{Ah}$ and glucocorticoid receptors in the synergistic induction of cleft palate by TCDD and hydrocortisone. Toxicol Appl Pharmacol 1994; 128: 138-50.

[19] Theobald HM, Roman BL, Lin T-M, Ohtani S, Chen S-W, Peterson RE. 2,3,7,8-Tetrachlorodibenzo-p-dioxin inhibits luminal cell differentiation and androgen responsiveness of the ventral prostate without inhibiting prostatic dihydrotesterone.formation or testicular androgen production in rat offspring. Toxicol Sci 2000; 58: 324-38.

[20] Parks L, Ostby J, Lambright C, et al. The plasticizer diethylphthalate induces malformations by decreasing fetal testosterone synthesis during sexual differentiation in the male rat. Toxicol Sci 2000; 58: 339-49.

[21] Gray L, Jr, Ostby J, Furr J, Price M, Veeramachaneni D, Parks L. Perinatal exposure to the phthalates DEHP, BBP, and DINP, but not DEP, DMP, or DOTP, alters sexual differentiation of the male rat. Toxicol Sci 2000; 58: 350-65.

[22] Laws SC, Ferrell JM, Stoker TE, Schmid J, Cooper RL. The effects of atrazine of female Wistar rats: an evaluation of the protocol for assessing prenatal development and thyroid function. Toxicol Sci 2000; 58: 366-76.

[23] Chen PH, Hsu ST. PCB poisoning from toxic rice-bran oil in Taiwan. In: Waid JS, Ed., PCBs and the environment. CRC Press, Boca Raton FL 1987; vol. 3.
[24] Hoffman RE. Recent studies of the human immunotoxic effects of 2,3,7,8-tetrachlorodibenzo-p-dioxin. Clinical Immunotoxicology, In: Newcombe DS, Rose NR, Bloom JC, Eds. Raven Press, New York 1992; pp. 339-48.

[25] De Swart RI, Kluten RMG, Huizing CJ, et al. Mitogen and antigen induced $\mathrm{B}$ and $\mathrm{T}$ cell responses of peripheral blood mononuclear cells from the harbour seal (Phoca vitulina). Vet Immunol Immunopathol 1993; 37: 217-30.

[26] Colborn T, Clement C. Chemically-induced alterations in sexual and functional development: the wildlife/human connection. Princeton, NJ: Princeton Scientific Publishing 1993.

[27] Kelce WR, Monosson E, Gamcsik MP, Laws SC, Gray LE. Environmental hormone disrupters - evidence that vinclozolin developmental toxicity is mediated by antiandrogenic metabolites. Toxicol Appl Pharmacol 1994; 126(2): 276-85.

[28] Brouwer A, Ahlborg UG, Vandenberg M, et al. Functional aspects of developmental toxicity of polyhalogenated aromatichydrocarbons in experimental animals and human infants. Eur J Pharmacol Environ Toxicol 1995; 293(1): 1-40.

[29] Guillette LJ, Pickford DB, Crain DA, Rooney AA, Percival HF. Reduction in penis size and plasma testerone concentrations in juvenile alligators living in a contaminated environment. Gen Comp Endocrinol 1996; 101(1): 32-42.

[30] Santostefano MJ, Wang X, Richardson VM, Ross DG, DeVito MJ, Birnbaum LS. A pharmacodynamic analysis of TCDD-induced cytochrome P450 gene expression in multiple tissues: dose-and timedependent effects. Toxicol Appl Pharmacol 1998; 151: 294-310.

[31] Roman B, Peterson R. In utero and lactational exposure of the male rat to 2,3,7,8-tetrachlorodibenzo-p-dioxin impairs prostate development: Effects on gene expression. Toxicol Appl Pharmacol 1998; 150: 240-53.

[32] Roman B, Timms B, Prins G, Peterson R. In utero and lactational exposure of the male rat to 2,3,7,8-tetrachlorodibenzo-p-dioxin impairs prostate development: effects on growth and cytodifferentiation. Toxicol Appl Pharmacol 1998; 150: 254-70.

[33] Miller S, Kennedy D, Thomson J, et al. A rapid and sensitive reporter gene system using green fluorescent protein expression to detect chemicals with estrogenic activity. Toxicol Sci 2000; 55: 6977.

[34] ATSDR Toxicological profile for di-n-butyl Phthalate (DBP): Agency for toxic registry. 2001; Available from: http://www. atsdr.cdc.gov/toxicprofiles/tp135.html

[35] Nassberger L, Arbin A, Ostelius JM. Exposure of patients to phthalates from polyvinyl chloride tubing used for dialysis. Nephron 1987; 154: 286-90.

[36] Bradbury J. UK panics over phthalates in baby milk formula. Lancet 1996; 347: 1541.

[37] ATSDR Toxicological profile for diethylphthalate (DEP): Agency for toxic registry. 1995; Available from: http://www.atsdr.cdc. gov/toxicprofiles/tp73.html

[38] ATSDR Toxicological profile for di(2ethylhexyl)phthalate (DEHP): Agency for toxic registry. 2002; Available from: http://www.atsdr. cdc.gov/toxicprofiles/tp9.html

[39] Silva MJ, Barr DB, Reidy JA, et al. Urinary levels of seven phthalate metabolites in the U.S. population from the National Health and Nutrition Examination Survey (NHANES) 1999-2000. Environ Health Perspect 2004; 112 (3): 331-8.

[40] Phillips KP, Tanphaichitr N. Human exposure to endocrine disruptors and semen quality. J Toxicol Environ Health B Crit Rev 2008; 11(3-4): 188-220.

[41] Hogberg J, Hanberg A, Berglund M, et al. Phthalate esters and their metabolites in human breast milk, blood or serum, and urine as biomarkers of exposure in vulnerable populations. Environ Health Perspect 2008; 116(3): 334-9.

[42] Parveen M, Inoue A, Ise R, Tanji M, Kiyama R. Evaluation of estrogenic activity of phthalate esters by gene expression profiling using a focused microarray (estrarray $(\mathrm{R})$ ). Environ Toxicol Chem 2008; 9: 1 (ahead of print).

[43] Howdeshell KL, Wilson VS, Furr J, et al. A mixture of five phthalate esters inhibits fetal testicular testerone production in the Sprague Dawley rat in a cumulative, dose additive manner. Toxicol Sci 2008; (epublished ahead of print).

[44] Hauser R, Sokol R. Science linking environmental contaminant exposures with fertility and reproductive health. Fertil Steril 2008; (Suppl 2): e59-65. 
[45] Aarskog D. A familial syndrome of short stature associated with facial dysplasia and genital anomalies. J Pediatr 1970; 77: 856-61.

[46] Orrico A, Galli L, Buoni S, et al. Attention-deficit/hyperactivity disorder (ADHD) and variable clinical expression of Aarskog-Scott syndrome due to a novel FGD1 gene mutation (R408Q). Am J Med Genet 2005; 35A: 99-102.

[47] Orrico A, Galli L, Cavaliere ML, et al. Phenotypic and molecular characterisation of the Aarskog-Scott syndrome: a survey of the clinical variability in light of FGD1 mutation analysis in 46 patients. Eur J Hum Genet 2004; 12: 16-23.

[48] Fryns JP. Aarskog syndrome: the changing phenotype with age. Am J Med Genet 1992; 43: 420-7.

[49] Pasteris N, Cadle A, Logie L. Isolation and characterization of the faciogenital dysplasia (Aarskog-Scott Syndrome) gene: a putative Rho/Rac guanine nucleotide exchange factor. Cell 1994; 79: 66978.

[50] Sugarman GI, RimoinDL, Lachman RS. The facial-digital-genital (Aarskog) syndrome. Am J Dis Child 1973; 126: 248-52.
[51] Grier RE, Harrington FH, Kendig R, Mamunes P. Autosomal dominant inheritance of the Aarskog syndrome. Am J Med Genet 1983; 15: 39-46.

[52] Bawle E, Tyrkus M, Lipman S, Bozimowski D. Aarskog syndrome: full male and female expression associated with an $\mathrm{X}$ autosome translocation. Am J Med Genet 1984; 17: 595-602.

[53] Eddy RL, Kretschmer PJ, Fairhurst JL, et al. A human gene family of neurite outgrowth-promoting proteins: heparin-binding neurite outgrowth promoting factor maps to $11 \mathrm{p} 11-11 \mathrm{p} 13$. (Abstract) $\mathrm{Cy}$ togenet Cell Genet 1991; 58: 1958.

[54] Kaname T, Kuwano A, Murano I, Uehara K, Muramatsu T, Kajii T. Midkine gene MDK), a gene for prenatal differentiation and neuroregulation, maps to band $11 \mathrm{p} 11.2$ by fluorescence in situ hybridization. Genomics 1993; 17: 514-15.

[55] O'Hara B, Jenkins NA, Gilbert DJ, et al. Chromosomal assignment of the heparin-binding cytokine genes MDK and PTN in mouse and man. Cytogenet Cell Genet 1995; 69: 40-3.

(C) Hokanson et al.; Licensee Bentham Open.

This is an open access article licensed under the terms of the Creative Commons Attribution Non-Commercial License (http://creativecommons.org/licenses/ by-nc/3.0/) which permits unrestricted, non-commercial use, distribution and reproduction in any medium, provided the work is properly cited. 